PEMBELAJAR: Jurnal Ilmu Pendidikan, Keguruan, dan Pembelajaran

Volume 2 Nomor 1 April 2018 hal 25-34

e-ISSN: 2549-9114 dan p-ISSN: 2549-9203

(Received: Januari-2018; Reviewed: Maret-2018; Published: April 2018)

\title{
Karakter Kebangsaan Pada Buku Siswa Kelas 4 Tema "Pahlawanku": Sebuah Implementasi
}

\author{
Tyas Ani Riyana ${ }^{\mathrm{a}}$, Abdul Salim ${ }^{\mathrm{a}}$, Winarno ${ }^{\mathrm{b}}$ \\ aPendidikan Luar Biasa Universitas Sebelas Maret, Surakarta, Indonesia \\ ${ }^{b}$ Dosen Program Studi PPKn Universitas Sebelas Maret, Surakarta, Indonesia \\ Corresponding e-mail: tyas.riyana@icloud.com
}

\begin{abstract}
Abstrak. Penelitian ini bertujuan untuk mengetahui rancangan yang dibuat guru kelas dalam mengimplementasikan nilai karakter kebangsaan, mengetahui implementasi nilai karakter kebangsaan pada proses pelaksanaan pembelajaran, mengetahui faktor penunjang dan faktor penghambat dalam mengimplementasikan karakter kebangsaan dalam kegiatan pembelajaran , mengetahui upaya-upaya guru untuk mengatasi faktor penghambat dalam mengimplementasikan nilai karakter kebangsaan pada tema "Pahlawanku" di SD Negeri Sidorejo 01. Penelitian ini menggunakan pendekatan deskriptif kualitatif, bahwa peneliti ingin memahami implementasi nilai karakter kebangsaan dalam pembelajaran tema "Pahlawanku" di SD Negeri Sidorejo 01. Sumber data primer diperoleh dari buku tematik siswa kelas 4 terbitan Kemendiknas, guru kelas dan siswa kelas 4. Sumber sekunder diperoleh dari RPP dan silabus pelaksanaan pembelajaran tema "Pahlawanku". Teknik pengumpulan data adalah analisis dokumen, observasi, wawancara mendalam dan dokumentasi. Untuk teknik analisis data dengan menggunakan reduksi data, penyajian data dan diakhiri dengan penarikan kesimpulan. Hasil dari penelitian ini adalah implementasi nilai karakter kebangsaan pada proses pembelajaran sudah baik, melalui beberapa factor penunjang yang ada mampu menutupi beberapa factor yang menjadi penghambat dalam pelaksanaannya..
\end{abstract}

Kata Kunci: karakter kebangsaan, nasionalisme, nasionalis, buku tema

Abstract: This article aims to determine the design created classroom teachers in implementing value national character, knowing the implementation value of national character on the implementation process of learning, knowing the factors supporting and inhibiting factors in implementing the national character in the learning activities, knowing the efforts of teachers to overcome the limiting factor in the implementation of the value of national character on the theme of "Pahlawanku" in SD Negeri Sidorejo 01. This study used a qualitative descriptive approach, that researchers want to understand the implementation of national character value in learning the theme of "Pahlawanku" in elementary school Sidorejo 01 . The primary data source is obtained from grade 4 thematic books published Kemendiknas, the class teacher and students in grade 4. A secondary source is obtained from the lesson plan and the implementation of learning syllabus theme "Pahlawanku". Data collection techniques are document analysis, observation, interview and documentation. For data analysis techniques using data reduction, data presentation and ends with a conclusion. Results of this research is the implementation of national character value in the learning process has been good, with some existing supporting factors able to cover some of the factors that become an obstacle in its implementation.

Keywords: nationalism character, nationalism, nationalist, thematic book 


\section{PENDAHULUAN}

Dimulai pada tanggal 17 Agustus 1945 bangsa Indonesia memproklamasikan kemerdekaan Indonesia dan para bapak pendiri bangsa menyadari bahwa ada tiga tantangan besar yang harus dihadapi. Pertama, adalah mendirikan negara yang bersatu dan berdaulat. Kedua, adalah membangun bangsa dan yang ketiga adalah membangun karakter. Ketiga hal tersebut secara jelas tertuang dalam konsep negara bangsa (nation-state) dan pembangunan karakter bangsa (nation and character building). Bung Karno pernah menegaskan bahwa bangsa Indonesia harus membangun diri dengan mendahulukan pembangunan karakter (character building), karena dari sinilah yang akan membuat Indonesia menjadi bangsa yang besar, maju dan jaya, serta bermartabat, namun bila character building ini tidak segera dilakukan, maka bangsa Indonesia hanya akan menjadi bangsa kuli (Samani dan Hariyanto: 2012). Dalam tujuan pendidikan karakter bangsa yang dituangkan dalam pendidikan karakter meliputi: (1) Mengembangkan potensi afektif siswa sebagai manusia dan warga negaranya yang memiliki nilai-nilai karakter bangsa; (2) mengembangkan kebiasaan dan perilaku siswa yang terpuji dan sejalan dengan nilai-nilai universal dan tradisi budaya bangsa yang religius; (3) menanamkan jiwa kemimpinan dan tanggung jawab pada siswa untuk menjadi manusia yang mandiri, kreatif, berwawasan kebangsaan; (4) mengembangkan lingkungan kehidupan sekolah sebagai lingkungan belajar yang aman, jujur, penuh kreativitas, dan persahabatan, serta dengan rasa kebangsaan yang tinggi dan penuh kekuatan (Martini:2013)

Karakter atau sering disebut dengan watak berasal dari kata Yunani "charassein" yang berarti barang atau alat untuk menggores, yang dikemudian hari dipahami sebagai stempel/cap. Jadi, watak itu sebuah stempel atau cap, sifatsifat yang melekat pada seseorang (S.M Dumadi, 1955:11 dalam Sutarjo Adi Susilo). Arti ini sama dengan istilah karakter" dalam bahsa Inggris (character) yang juga berarti mengukir, melukis, memahatkan atau menggoreskan. (Echols dan Shadily, 1995:214) dalam Suyadi. karakter secara kebahasaan yang lain adalah huruf, angka, ruang atau symbol khusus yang dapat dimunculkan pada layer denga papan ketik (Pusat Bahasa Depdiknas, 2008:682) dalam Suyadi.
Character is a special characteristic that inherent in a person, family and community. Character is a consistent and predictable shown by tendenvy of behavior (Fahmy:2015)

Sesuai dengan tujuan pendidikan karakter untuk generasi emas tahun 2045 (Rokhman:2013), melalui Undang-Undang Nomor 20 tahun 2003 tentang Sistem Pendidikan Nasional pada pasal 3 seharusnya menjadi stimulant terbaik untuk memberikan ruh berkembangnya pendidikan karakter bagi civitas akademika dalam beraktivitas di lapangan.

Kebangsaan berasal dari kata bangsa atau "nation" yang diartikan sebagai kelompok manusia yang bersak dari keturunan nenek moyang yang sama (SA. Kodhi, 1988:83-84). Menurut Benedict Anderson (2002:8) nation didefinisikan sebagai sebuah komunitas politik terbayang. Nation pada awalnya lebih dalam imaginasi pekerjaan belaka, namun kemudian nation terbayangkan sebagai komunitas dan diterima sebagai persahabatan yang kuat dan dalam. Nation adalah jiwa dan prinsip spiritual yang menjadi ikatan bersama baik dalam pengorbanan (soerifice) maupun dalam kebersamaan (solidarity), Ernest Renan yang dikutip oleh Sri Sultan Hamengkubuwono X (2004:10). Menurut Koch (2016):

"The nationalist principle of congruency between the nation and the state is enacted through a wide range of political practices, institutions, and symbols"

Salah satu prioritas Gerakan PPK yang sesegera mungkin harus ditanamkan pada generasi-generasi penerus bangsa sedini mungkin, sesuai dengan isi Buku Saku Panduan Penilaian Pendidikan karakter (Kemendiknas:2017) di antaranya adalah karakter nasionalis yangmana dalam pendikar tahun 2010 disebut sebagai karakter kebangsaan. Nilai karakter nasionalis merupakan cara berpikir, bersikap, dan berbuat yang menunjukkan kesetiaan, kepedulian, dan penghargaan yang tinggi terhadap bahasa, lingkungan fisik, sosial, budaya, ekonomi, dan politik bangsa, menempatkan kepentingan bangsa dan negara di atas kepentingan diri dan kelompoknya. Subnilai nasionalis antara lain apresiasi budaya bangsa sendiri, menjaga kekayaan budaya bangsa, rela berkorban, unggul, dan berprestasi, cinta tanah air, menjaga lingkungan, taat hukum, disiplin, menghormati keragaman budaya, suku dan agama. 
Sebagai seorang pendidik dalam hal ini guru, perlu menyiapkan kegiatan pembelajaaran harus bersiap dengan perencanaan pembelajaran meliputi silabus dan Rancangan Pelaksanaan Pembelajaran (RPP). Silabus sebagai dokumen acuan untuk penyusunan RPP yang dibuat oleh guru sebelum proses pembelajaran. Sebagaimana dalam kurikulum yang sudah ada, bahwa silabus dikembangkan berdasarkan standar isi pada Permendiknas nomor 22 tahun 2006.

\section{METODE}

Kegiatan penelitian ini menggunakan pendekatan kualitatif. Hal ini dikarenakan peneliti ingin mengetahui secara menyeluruh proses implementasi nilai karakter kebangsaan yang diaplikasikan guru dalam pembelajaran tema "pahlawaku" oleh SD Negeri Sidorejo 1. Moleong (2010: 168) mengatakan kedudukan peneliti dalam penelitian kualitatif cukup rumit. Peneliti sekaligus merupakan perencana, pelaksana pengumpul data, melakukan analisis, penafsiran data dan menjadi pelopor dari hasil penelitiannya. Penelitian ini menggunakan jenis penelitian studi kasus yang mengeksplorasi masalah dengan batasan terinci, data yang mendalam dan menyertakan berbagai sumber informasi. Penelitian dilakukan secara intensif, terinci, dan mendalam terhadap suatu lembaga atau suatu gejala tertentu. Dalam studi kasus peneliti harus senantiasa mengumpulkan data setepat-tepatnya dan selengkap-lengkapnya dari kasus yang diangkat untuk mengetahui aspekaspek menurut urutannya yang dihubungkan satu dengan yang lainnya secara menyeluruh dan integral agar menghasilkan gambaran umum tentang kasus yang akan diselidiki. Studi kasus yang diangkat dalam penelitian ini yaitu mengenai pengimplementasian nilai karakter kebangsaan dalam pembelajaran tema "Pahlawanku". Penelitian ini dilaksanakan di SD Negeri Sidorejo 01 Kecamatan Bendosari kabupaten Sukoharjo. Prosedur pengumpulan data yang dilakukan oleh peneliti dalam penelitian ini meliputi, analisis isi dokumen, observasi, wawancara mendalam dan dokumentasi. Aktifitas dalam analisis data, yaitu data reduction, data display dan conclusion drawing/verification.

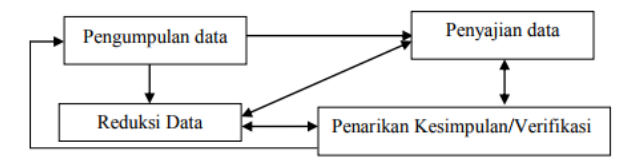

Sumber: Sugiyono.2008:92. Metode Penelitian Kuantitatif, Kualitatif dan $R \& D$

Sugiyono (2010:267) mengatakan dalam penelitian kualitatif, temuan atau data dapat dinyatakan valid apabila tidak ada perbedaan antara yang dilaporkan peneliti dengan apa yang sesungguhnya terjadi pada objek yang diteliti. Tetapi kebenaran realitas data penelitian kualitatif bersifat jamak. Dalam pengecekan keabsahan data yang dilakukan peneliti dalam penelitian ini meliputi, perpanjangan pengamatan, peningkatan ketekunan, triangulasi, dan diskusi teman sejawat.

\section{HASIL DAN PEMBAHASAN}

\subsection{Sebaran subnilai nasionalis dalam implementasi Nilai Karakter kebangsaan pada tema "Pahlawanku"}

\begin{tabular}{|l|l|l|}
\hline Judul Buku & Daftar Isi & Halaman \\
\hline \multirow{3}{*}{ Pahlawanku } & $\begin{array}{l}\text { Subtema 1 } \\
\text { Perjuangan para Pahlawan }\end{array}$ & 1 \\
\cline { 2 - 3 } & $\begin{array}{l}\text { Subtema 2 } \\
\text { Pahlawanku Kebangganku }\end{array}$ & 53 \\
\cline { 2 - 3 } & Subtema 3 & 93 \\
\hline
\end{tabular}




\begin{tabular}{|l|l|l|}
\hline & Sikap Pahlawan & \\
\hline
\end{tabular}

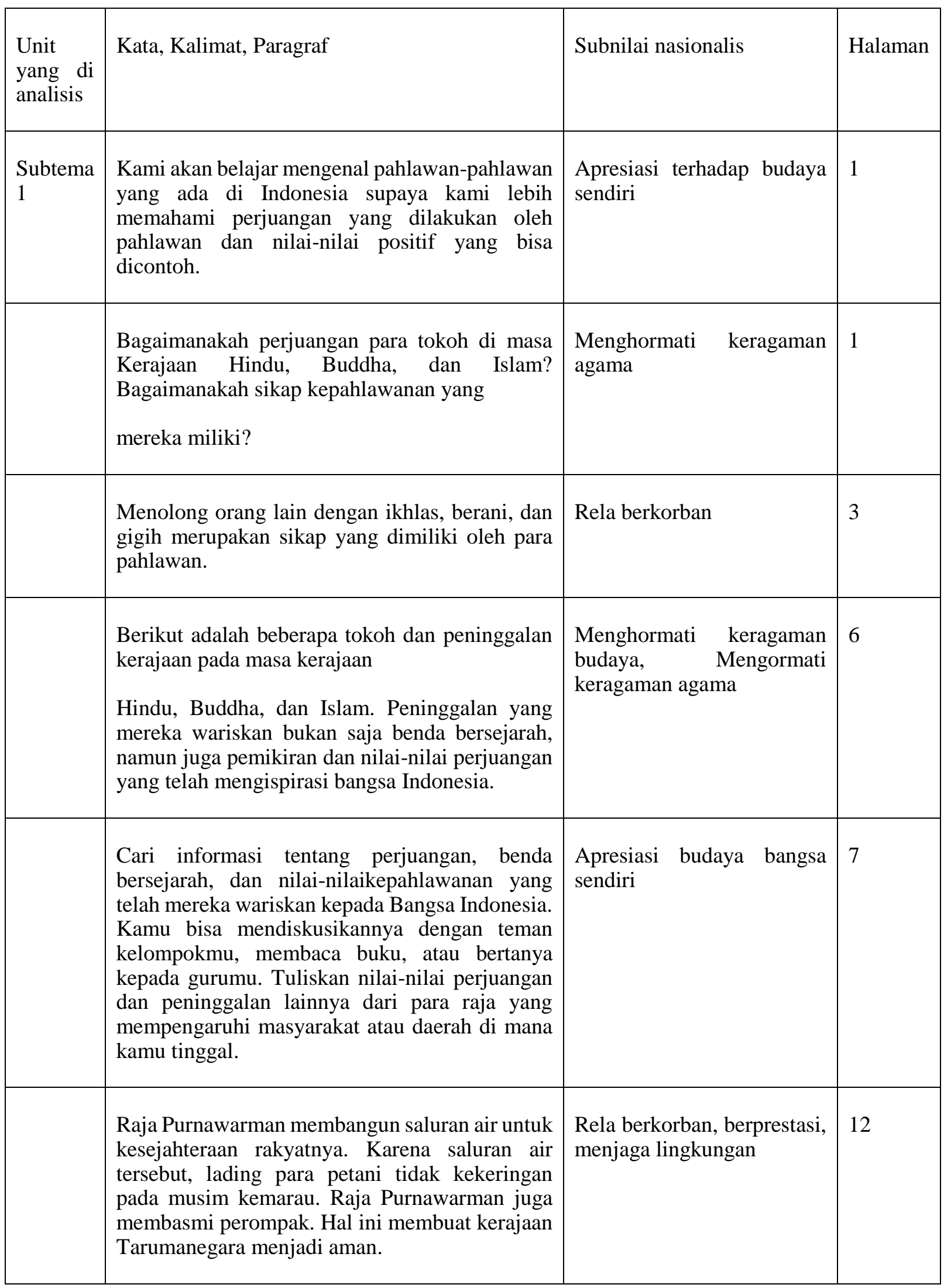




\begin{tabular}{|c|c|c|c|}
\hline & $\begin{array}{l}\text { Tahukah kamu? Sila ke empat: Kerakyatan yang } \\
\text { Dipimpin oleh Hikmat Kebijaksanaan dalam } \\
\text { Permusyawaratan Perwakilan. Makna sila ke } \\
\text { empat adalah mendahulukan kepentingan dan } \\
\text { tujuan bersama cinta permusyawaratan dan } \\
\text { demokrasi, dan bijak menyelesaikan masalah. }\end{array}$ & Rela berkorban & 12 \\
\hline & $\begin{array}{l}\text { Balaputradewa berjuang membangun armada } \\
\text { laut dan menjadikan Sriwijaya kerajaan yang } \\
\text { makmur }\end{array}$ & Unggul, berprestasi & 30 \\
\hline & $\begin{array}{l}\text { Pada tahun 1336, Gajah Mada mengucapkan } \\
\text { Sumpah Palapa, yaitu janji bahwa ia tidak akan } \\
\text { memakan buah palapa, sejenis rempah-rempah, } \\
\text { bila belum berhasil menguasai pulau-pulau di } \\
\text { Nusantara. }\end{array}$ & $\begin{array}{l}\text { Rela berkorban, disiplin, } \\
\text { cinta tanah air }\end{array}$ & 39 \\
\hline & $\begin{array}{l}\text { Salah satu upaya yang dilakukan Pangeran } \\
\text { Diponegoro dalam perjuangannya adalah } \\
\text { menyatukan seluruh rakyat pribumi dalam } \\
\text { semangat "Sadumuk bathuk, sanyari bumi ditohi } \\
\text { tekan pati“; sejari kepala, sejengkal tanah, dibela } \\
\text { sampai mati. Usaha ini berhasil karena disertai } \\
\text { dengan memelopori, mencontohkan, dan } \\
\text { memberikan komando yang jelas kepada semua } \\
\text { rakyat, khususnya di Pulau Jawa. }\end{array}$ & $\begin{array}{l}\text { Cinta tanah air, rela } \\
\text { berkorban, unggul }\end{array}$ & 50 \\
\hline \multirow[t]{4}{*}{$\begin{array}{l}\text { Subtema } \\
2\end{array}$} & $\begin{array}{l}\text { Ketika masa kerajaan Hindu-Buddha mulai } \\
\text { melemah, masuklah agama Islam di wilayah } \\
\text { Indonesia. Siapa yang mempunyai peranan } \\
\text { penting di masa kerajaan Islam? }\end{array}$ & $\begin{array}{l}\text { Menghormati keragaman } \\
\text { agama }\end{array}$ & 53 \\
\hline & $\begin{array}{l}\text { Sultan Hasanuddin berusaha untuk melawan } \\
\text { kesewenang-wenangan Belanda. Perjuangan } \\
\text { beliau layak diteladani dan diberi penghargaan. } \\
\text { Berbagai peninggalan Sultan Hasanuddin juga } \\
\text { perlu terus dilestarikan sebagai pelajaran bagi } \\
\text { generasi berikutnya. }\end{array}$ & Rela berkorban, taat hukum & 53 \\
\hline & $\begin{array}{l}\text { Dengan prestasinya, Yoga berhasil membuktikan } \\
\text { bahwa semangat dan kerja keras bisa } \\
\text { mengalahkan keterbatasan. Selalu ada jalan bagi } \\
\text { mereka yang mau berusaha }\end{array}$ & $\begin{array}{l}\text { Disiplin, rela berkorban, } \\
\text { unggul, berprestasi }\end{array}$ & 62 \\
\hline & $\begin{array}{l}\text { Sila ke lima : Keadilan sosial bagi seluruh rakyat } \\
\text { Indonesia Sila ini bermakna } \\
\text { •• Adil, bukan sama }\end{array}$ & $\begin{array}{l}\text { Apresiasi budaya bangsa } \\
\text { sendiri, menghormati } \\
\text { keragaman suku, agama dan } \\
\text { budaya }\end{array}$ & 63 \\
\hline
\end{tabular}




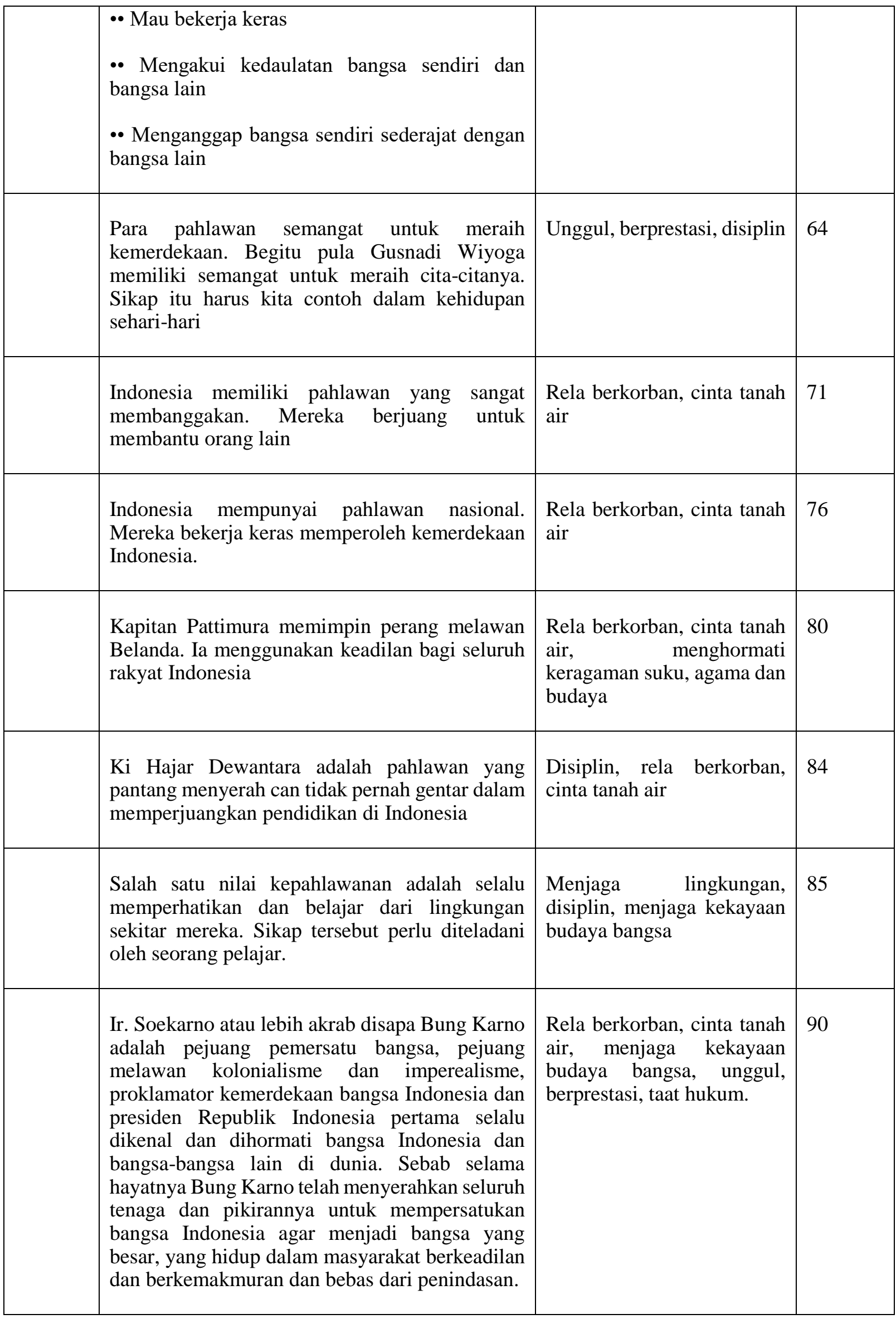




\begin{tabular}{|c|c|c|c|}
\hline & $\begin{array}{l}\text { Upaya Bung karno untuk menciptakan } \\
\text { masyarakat berkeadilan dan berkemakmuran } \\
\text { sejalan dengan sila ke lima Pancasila, yaitu } \\
\text { keadilan Sosial bagi Seluruh Rakyat Indonesia. }\end{array}$ & $\begin{array}{l}\text { Cinta tanah air, disiplin, } \\
\text { disiplin }\end{array}$ & 91 \\
\hline & $\begin{array}{l}\text { Sikap yang menunjukkan keadilan sosial juga } \\
\text { dapat kita tunjukkan dalam kehidupan sehari- } \\
\text { hari. Salah satu contohnya adalah membantu } \\
\text { mereka yang berada dalam kesulitan }\end{array}$ & $\begin{array}{l}\text { Rela berkorban, menjaga } \\
\text { lingkungan }\end{array}$ & 92 \\
\hline \multirow[t]{6}{*}{$\begin{array}{l}\text { Subtema } \\
3\end{array}$} & $\begin{array}{l}\text { Kemerdekaan yang kita nikmati sekarang ini } \\
\text { tidak terlepas dari perjuangan dan pengorbanan } \\
\text { yang dilakukan oleh para pahlawan. Mereka } \\
\text { bukan hanya mengorbankan harta, namun juga } \\
\text { jiwa dan raga. Karena perjuangan mereka, kita } \\
\text { dapat menikmati kebebasan; kebebasan dalam } \\
\text { menentukan cita-cita, mendapatkan pendidikan, } \\
\text { serta kebebasan mengemukakan pendapat. }\end{array}$ & $\begin{array}{l}\text { Rela berkorban, cinta tanah } \\
\text { air, menjaga kekayaan } \\
\text { budaya bangsa }\end{array}$ & 94 \\
\hline & $\begin{array}{l}\text { Panas terik atau guyuran air hujan tidak pernah ia } \\
\text { pedulikan. Begitu juga dengan suara bising } \\
\text { kendaraan. Ia tidak pernah terganggu dengan } \\
\text { semua itu. Bahkan, umpatan dari mereka yang } \\
\text { marah karena Gimin menutup pintu rel pun ia } \\
\text { abaikan. Di dalam pikirannya yang ada hanyalah } \\
\text { cara untuk menyelamatkan orang-orang }\end{array}$ & $\begin{array}{l}\text { Rela berkorban, unggul, } \\
\text { menjaga lingkungannya }\end{array}$ & 111 \\
\hline & $\begin{array}{l}\text { Bung Tomo adalah tokoh populer pada peristiwa } \\
\text { Pertempuran } 10 \text { November di Surabaya. Ia } \\
\text { seorang pembakar semangat juang untuk } \\
\text { bertempur sampai titik darah penghabisan. } \\
\text { Beliau mempertahankan harga diri, tanah air, dan } \\
\text { bangsa yang telah diproklamasikan pada tanggal } \\
17 \text { Agustus } 1945\end{array}$ & $\begin{array}{l}\text { Rela berkorban, cinta tana } \\
\text { air, unggul }\end{array}$ & 116 \\
\hline & $\begin{array}{l}\text { Sultan Iskandar Muda, manusia yang seluruh } \\
\text { hidupnya diserahkan mutlak bagi negara dan } \\
\text { kebesaran bangsa yang peduli terhadap } \\
\text { kesejahteraan rakyat Aceh. }\end{array}$ & $\begin{array}{l}\text { Rela berkorban, cinta tanah } \\
\text { air, menjaga lingkungan, } \\
\text { menjaga kekayaan budaya } \\
\text { bangsa }\end{array}$ & 124 \\
\hline & $\begin{array}{l}\text { Kini Kakek Juhaeri menuai kebahagiaan dari apa } \\
\text { yang ditabur. Hanya dengan upaya sederhana, } \\
\text { Juhaeri ternyata mampu mengubah dari tiada } \\
\text { menjadi ada. Dari kerusakan menjadi keteduhan. } \\
\text { Untuk berbuat baik, perlu usaha yang tiada henti. }\end{array}$ & $\begin{array}{l}\text { Menjaga kekayaan budaya } \\
\text { bangsa, unggul, berprestasi, } \\
\text { rela berkorban }\end{array}$ & 131 \\
\hline & $\begin{array}{l}\text { Membantu orang-orang di sekitar kita yang } \\
\text { mengalami kecelakaan adalah merupakan salah }\end{array}$ & $\begin{array}{l}\text { Menjaga lingkungann, taat } \\
\text { hukum, rela berkorban }\end{array}$ & 133 \\
\hline
\end{tabular}


satu bentuk tanggung jawab sosial yang sesuai denga sila ke- 5 Pancasila.

\subsection{Rancangan yang dibuat Guru kelas dalam Mengimplementasikan Nilai Karakter kebangsaan pada tema "Pahlawanku"}

Perencanaan pembelajaran yang dirancang guru kelas di SD Negeri Sidorejo 01 merupakan acuan proses pembelajaran. Dengan adanya perencanaan pembelajaran akan mempermudah guru dalam melaksanakan proses pembelajaran karena alurnya sudah diletakkan sesuai porsinya, sehingga hasil belajar siswa sesuai dengan yang diharapkan. Perencanaan tersebut meliputi silabus dan Rancangan Pelaksanaan Pembelajaran (RPP). Penyusunan Rencana Pelaksanaan Pembelajaran dilakukan dengan cara: 1. Mengetahui SK/KD yang akan digunakan dalam proses pembelajaran; 2 . Merumuskan indikator yang akan dicapai sesuai dengan Kompetensi Dasar yang akan dibahas; 3. Merumuskan indikator karakter kebangsaan yang akan dicapai dalam Kompetensi Dasar yang akan dibahas; 4. Merumuskan tujuan pembelajaran yang mengembangkan karakter siswa; 5 . Menggunakan metode yang bervariasi serta menggunakan strategi kooperatif; 6 . Menentukan materi sesuai dengan Kompetensi Dasar yang akan dibahas; 7. Membuat dan mengembangkan langkah pembelajaran untuk mengetahui alur proses pembelajaran serta dapat terlaksana sesuai skenario yang direncanakan;

Berdasarkan paparan data yang telah ditemukan, peneliti dapat menyimpulkan bahwa rancangan yang dikembangkan dalam Rancangan Pelaksanaan Pembelajaran oleh guru kelas di SD Negeri sidorejo 01 telah mengandung nilai karakter kebangsaan.

\subsection{Implementasi Nilai Karakter kebangsaan pada proses Pelaksanaan Pembelajaran dalam pembelajaran tema "Pahlawanku" kelas 4}

Pada proses pelaksanaan pembelajaran materi terbagi tiga tahap yang memuat nilai karakter kebangsaan meliputi kegiatan awal, kegiatan inti, dan kegiatan akhir serta pengelolaan kelas yang termuat dalam pelaksanan pembelajaran. Dari proses pelaksanaan pembelajaran ditemukan subnilai karakter kebangsaan sebagai berikut:

Nilai karakter kebangsaan terlihat pada subtema 1, 2 dan 3. Materi dalam masing-masing tema memiliki nilai karakter kebangsaan terlihat pada pembahasan Pancasila dan pahlawan-pahlawan di Indonesia, pahlawan Nasional, Revolusi atau bahkan pahlawan pada bidang-bidang tertentu. Selain itu pada lembar diskusi, latihan dan evaluasi juga menampilkan indikator karakter kebangsaan yang didukung dengan 'eye cathcer' yang menarik. Nilai karakter kebangsaan pada proses pembelajaran terlihat pada saat kegiatan awal yang tercermin pada menyanyikan lagu Indonesia raya dan lagu nasional, pada kegiatan inti tercermin pada aktivitas pembeljaran dari buku tematik siswa dan di kegiatan akhir siswa diajak untuk menyanyikan lagu daerah oleh guru sebagai bentuk sikap menjaga budaya bangsa sendiri sesuai salah satu karakter kebangsaan (nasionalis).

Faktor Penghambat dan Faktor Pendukung dalam pengimplementasian Nilai Karakter kebangsaan pada tema "Pahlawanku" Kelas 4 antara lain

\subsubsection{Faktor penghambat}

Faktor penghambat atau kendala yang terlihat dalam mengimplementasikan nilai karakter kebangsaan dalam pembelajaran PPKn meliputi beberapa faktor yaitu; 1. Keluarga yang masih kurang peduli pada anaknya sebagai sebuah contoh yang akan diduplikasi siswa dalam proses pembelajaran yaitu kurang peduli terhadap esensi subnilai karakter kebangsaan yang disampaikan guru; 2. Suasana kelas yang kurang mendukung karena siswa menunjukkan sikap yang kurang antusias; 3 . Kurangnya kesadaran siswa terhadap hal-hal yang positif (baik), contohnya dalam mematuhi jadwal pelajaran yang telah ditentukan dengan memasukin kelas tepat waktu; 4. Metode pembelajaran guru masih belum berhasil maksimal memberikan pengaruh dan pengalaman belajar bermakna bagi para siswa untuk menstimulan subnilai karakter kebangsaan 
3.3.2 Faktor Pendukung

Faktor penunjang yang terlihat dalam mengimplementasikan nilai pendidikan karakter dalam pelajaran PKn meliputi beberapa faktor yaitu; 1. Penerapan kedisiplinan, penerapan yang dilakukan pada saat proses pembelajaran pada materi tema "Pahlawanku". Contohnya siswa harus disiplin dalam proses pembelajaran yang sedamg dilaksanakan dan mematuhi aturan guru dalam proses pembelajaran; 2 . Pemberian reward dan punishment, pemberian ini dimaksudkan untuk memantau perilaku siswa dalam berkegiatan di kelas. Dengan adanya reward dan punishment akan membuat siswa berhati-hati dalam bertingkah laku. Terutama dalam mengikuti proses pembelajaran pada Tema "Pahlawanku"

\section{KESIMPULAN}

Berdasarkan penelitian yang dilakukan peneliti tentang Implementasi Nilai Karakter kebangsaan dalam Pembelajaran Tema "Pahlawanku" SD Negeri Sidorejo 01 adalah sebagai berikut:

Buku tematik siswa sudat memuat karakter kebangsaan yang dapat menstimulasi anak untyuk lebih konsisten mengimplementasikanya. Rancangan pembelajaran yang dibuat guru pada tema "Pahlawanku" dalam mengimplementasikan nilai karakter kebangsaan adalah dengan memasukkannya di silabus dan RPP pada setiap komponen dalam perangkat pembelajaran. Nilai pendidikan karakter kebangsaan dalam silabus diwujudkan dengan langkah yang dilakukan oleh guru kelas dalam mengimplementasikan nilai karakter kebangsaan pada silabus yaitu: (1) Menganalisis SK KD untuk mengidentifikasi nilai karakter; (2) melakukan relevansi nilai karakter kebangsaan dengan kegiatan belajar, materi, indikator, penilaian, dan sumber belajar; (3) memasukkan nilai karakter kebangsaan. Sedangkankan dalam RPP nilai karakter diintegrasikan

dalam indikator pencapaian kompetensi, tujuan pembelajaran, materi pembelajaran, metode pembelajaran, langkah pembelajaran, dan evaluasi pembelajaran yang direlevakan dengan nilai karakter yang termuat buku tema "Pahlawanku". Implementasi nilai karakter kebangsaan pada proses pelaksanaan pembelajaran tema "Pahlawanku" terlihat pada kegiatan awal, kegiatan inti, dan kegiatan akhir serta dalam pengelolaan kelas. Peneliti berkesimpulan bahwa implementasi nilai karakter dalam proses pembelajaran Tema “pahlawanku' berkaitan dengan nilai karakter kebangsaan sudah tercapai meskipun belum maksimal. Materi yang dijelaskan oleh guru dalam kegiatan inti juga sudah memuat nilai karakter kebangsaan yang diinginkan sesuai RPP. Hal yang membuat belum maksimalnya pengimplementasian nilai karakter kebangsaan adalah pada saat pembelajaran menggunakan metode diskusi kelompok, siswa cenderung mengandalkan rekan-rekan mereka yang pada kesehariannya dianggap siswa sudah mampu melaksanaakan kegiatan sesuai dengan subnilai nasionalis yang dibahas oleh guru. Selain itu dalam pemberian tugas masih ada beberapa siswa yang tidak mengerjakan. Pengelolaan kelas pada awal pembelajaran sudah kondusif tetapi saat guru sedang menjelaskan materi siswa mulai kehilangan kendali konsentrasi, jadi dalam pengelolaan kelas masih belum sepenuhnya berhasil.

Faktor penghambat dan faktor penunjang dalam mengimplementasikan nilai karakter kebangsaan tentang materi pemberantasan korupsi meliputi beberapa faktor. Faktor penghambatnya yaitu kurangnya perhatian keluarga, keadaan kelas, dan kurangnya kesadaran siswa terhadap kegiatan positif. Faktor penunjang yaitu penerapan kedisiplinan, dan pemberian reward dan panishment.

\section{DAFTAR PUSTAKA}

Almonte, S. A. (2003). National Identity in Moral Education Textbooks for High School Students in the Philippines: A Content Analysis, 4(1), 19-26.

Amir, S. (2013). Pancasila As Integration Philosophy of Education And National Character. International Journal of Scientific \& Technology Research, 2(1). Retrieved from www.ijstr.org

Afandi, R. (2011). Integrasi Pendidikan Karakter dalam Pembelajaran IPS di Sekolah Dasar. Jurnal Pedagogia, 1(1), 85-98. Retrieved from http://publikasife.umsida.ac.id/files/RifkiV1.1.pdf

Silaban, W. (2012). Pemikiran Soekarno Tentang Nasionalisme, 1(3), 1-6.

Hakam, K. A. (2011). Pengembangan Model Pembudayaan Nilai-Moral dalam Pendidikan Dasar di Indonesia: Studi Kasus di Sekolah Dasar Negeri Bandungrejosari 1 Kota Malang , Jawa Timur, 4(229), 159-184.

Koch, N. (2016). Is nationalism just for nationals? Civic nationalism for 
noncitizens and celebrating National Day in Qatar and the UAE. Political Geography, 54, 43-53. https://doi.org/10.1016/j.polgeo.2015.09.0 06

Thornberg, R., \& Oğuz, E. (2013). Teachers' views on values education: A qualitative study in Sweden and Turkey. International Journal of Educational Research, 59, 4956. https://doi.org/10.1016/j.ijer.2013.03.005

Botterill, K., Hopkins, P., Sanghera, G., \& Arshad, R. (2016). Securing disunion: Young people's nationalism, identities and (in)securities in the campaign for an independent Scotland. Political Geography, 55, 124-134. https://doi.org/10.1016/j.polgeo.2016.09.0 02

Piang, B., Banu, N., Naidu, M., \& Osman, Z. J. (2017). The Journal of Social Studies Research Moral values and good citizens in a multi-ethnic society : A content analysis of moral education textbooks in Malaysia. The Journal of Social Studies Research.

https://doi.org/10.1016/j.jssr.2017.05.004

Muchtarom, M. (2017). The Ideology of Nationalism in Indonesia Civic Education Textbook, 6(9), 1-9.

Bengtsson, M. 2016. How to plan and performa qualitative study using content analysis in Nursing Plus Open, 2, (2016), 8-14

Benito, AE. 2009. The manual as text: The construction of an identity. In A.van Gorp $\& \mathrm{M}$.

Gaul, A. 2015. Security, Sovereignty, Patriotism Sinhalese Nationalism and the State in SriLanka History Textbooks, Ethnopolitics, from http://dx.doi.org/10.1080/17449057.2015. 1041834

Lestyarini, Beniati. 2012. Improving Nationalism to Strengthen the Character of Indonesia through Language Learning. Jurnal Pendidikan Karakter. Tahun II. Nomor 3. Oktober 2012
McCrone, D., \& Kiely, R. (2000). Nationalism and Citizenship. Sociology, 34(1), 19-34. https://doi.org/10.1017/S00380385000000 31Mulyasa, H. E., \& Aryani, W. D. (2017). Developing Religious Culture In School, 6(7)

Kemendiknas, Tema "Pahlawanku", Jakarta: Kemendiknas, 2016).

Budimansyah, Dasim. 2010. Penguatan Pendidikan Kewarganegaraan untuk Membangun Karakter Bangsa. Bandung: Widya Aksara.

Bungin, Burhan. 2011. Metodologi Penelitian Kualitatif. Jakarta: Raja Grafindo

Cebo, D. (2017). Characterization Of Bovine Adipose-Derived Stem Cells, 6(5), 5-7.

Creswell, John. W. 2012. Research Design: Pendekatan Kualitatif, kuantitatif dan Mixed. California: Sage Publication

Lickona, Thomas. 2012. Character matters. Jakarta: Bumi Aksara

Lickona, Thomas.2013. Pendidikan karakter: Panduan Lengkap Mendidik Siswa Menjadi Pintar dan Baik. Bandung: Nusa Media

Rivashinta, Emusti. 2012. Muatan Materi Pendidikan Karakter dalam Pembelajaran IPS Sejarah (Studi kasus di SMP Negeri Singkawang Utara Kota Singkawang. Tesis. Universitas Sebelas Maret. Tidak Dipublikasikan.

Chabibah, Latifatul.2015. Analisis Muatan NilaiNiilai Karakter pada Buku Siswa Kelas VI semester 2 Sekolah Dasar. Prosiding Seminar Nasional Univesrsitas Negeri Malang 